\title{
Foresight for all: Co-elaborative scenario building and empowerment
}

\author{
Robin Bourgeois ${ }^{a^{*}, 1}, E^{2}$ ther Penunia ${ }^{b}$, Sonali Bisht ${ }^{c}$, Don Boruk ${ }^{d}$ \\ ${ }^{a}$ French Agricultural Research Centre for International Development (CIRAD), Global Forum on \\ Agricultural Research (GFAR), c/o FAO-DDNG, Viale delle Terme di Caracalla, 00153 Rome, Italy \\ ${ }^{b}$ Asian Farmers' Association for Sustainable Rural Development (AFA), Rm 206, Partnership Center, \\ 59 \\ c. Salvador St., Loyola Heights, Quezon City 1108, Philippines c Institute of Himalayan Environmental \\ Research and Education (INHERE), Masi Bazar-263 658, Dist. Almora, Uttarakhand, India \\ ${ }^{d}$ Aliansi Petani Indonesia, East Nusa Tenggara Chapter, Boru, Flores, Indonesia \\ *Corresponding author. E-mail addresses: robin.bourgeois@cirad.fr (R. Bourgeois), \\ estherpenunia@gmail.com (E. Penunia),sonalibisht@yahoo.co.in (S. Bisht), \\ donborukdon@gmail.com (D. Boruk). \\ ${ }^{1}$ Present address: Centre for the Study of Governance Innovation (Govlnn), Department of Political \\ Sciences, University of Pretoria, Hatfield Campus, South Africa.
}

\section{Highlights}

- Development of a co-elaborative local level scenario building approach

- A framework linking the use of the future, empowerment and local agency

- Three case studies of local communities implementing the scenario approach for rural development

- Local community empowerment and potential for local agency is discussed.

\begin{abstract}
We present here a co-elaborative scenario building approach, called Participatory Prospective Analysis (PPA) and discuss its relevance for empowering local communities/organizations. This approach is adapted from the French "La Prospective". It is used as an action research engaging local farming communities in expanding their understanding of their own futures. Three cases of local implementation at farmer community level in India, Indonesia, and the Philippines illustrate how this approach was implemented. They are part of a global project in the field of food, agriculture and rural development, aiming at balancing the capacity to use the future, which is currently not fairly distributed to the detriment of local stakeholders, organizations and communities. Our results focus on the emergence of futures literacy as a capability, its connection to local agency and societal transformation. Our discussion highlights what in this approach makes the use of scenarios empowering, beyond its participatory features. The capacity to use the future has a great potential for local agency, even if it does not guarantee that communities will have the power or the willingness to directly engage in actions. Nevertheless, this approach seems to be a promising avenue for making everyone a future-literate potential agent of change.
\end{abstract}




\section{Graphical abstract}

Empowerment through co-elaborative scenario building

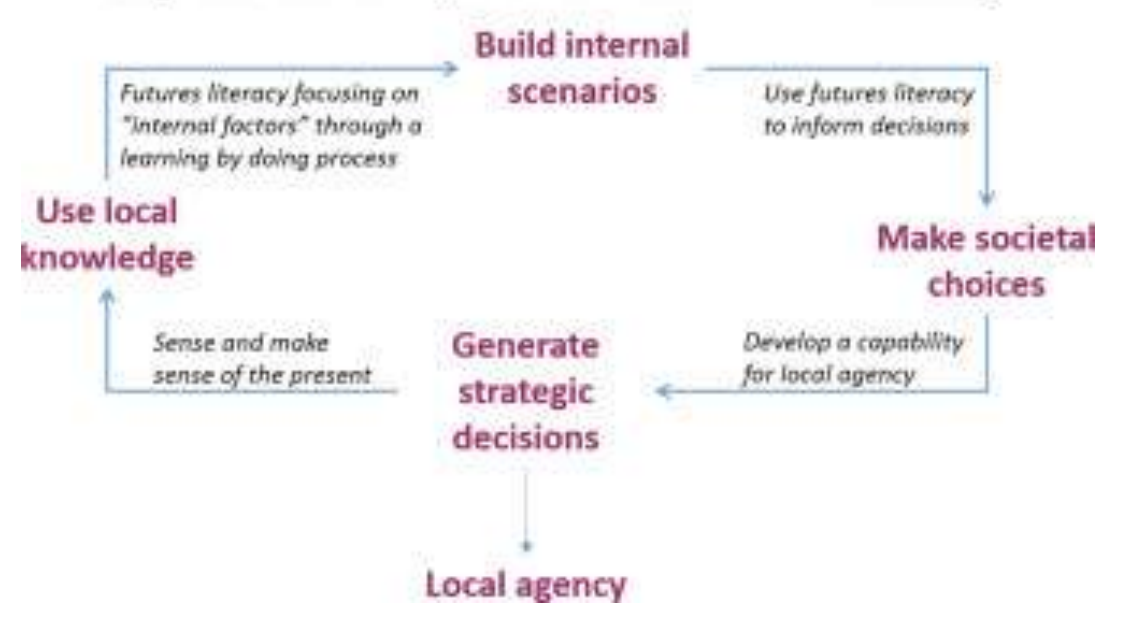

\section{Keywords}

Scenario; Co-elaboration; Futures literacy; Capability; Rural development; Local agency

\section{Introduction}

In this article we present a co-elaborative scenario building approach, called Participatory Prospective Analysis (PPA), and discuss its contribution to empowering local actors at grassroots level as a response to the following research question: how can we make the use of the future an emancipatory process? This approach forms part of a grassroots foresight initiative undertaken through the Global Forum on Agricultural Research (GFAR), which started at the second Global Conference on Agricultural Research for Development (GCARD2) organized by GFAR, where over 600 participants from agriculture-related sectors gathered to discuss future challenges for agricultural research (Holderness et al., 2013).

This research question is directly linked to the outcomes of GCARD2 where an inventory of Futures Studies on food, agriculture and rural development was prepared for, and reported during, its foresight sessions. The report showed that the capacity to use the future for shaping agricultural research and policy agendas, worldwide, regionally and nationally was not evenly distributed to the detriment of those who are the most affected by research and policies outputs, i.e. local farmers and farmer organizations and communities (Bourgeois, 2012). With evidence of such an unbalanced situation, aware about the control those who can use the future have over political agendas, and convinced that the future can be used to better understand the present and open up avenues for actions (Blackman and Henderson, 2004; De Smedt et al., 2013; Slaughter, 2002; Wilkinson et al., 2014), farmers organizations at GCARD2 stood for their right to play a major role in determining their own future. They advocated for developing their own capacity to produce the knowledge required for exploring the future, to use that knowledge to engage in shaping the future the way they want it, to become pro-active, future-smart agents of change. They called for a grassroots foresight initiative supporting them in using the future as part of an empowerment 
process $^{2}$. Empowerment was considered at two connected levels: more pro-active grassroots organizations locally engaged in using the future to sense and make sense of the present, and more inclusive future-oriented global debates regarding agricultural research and rural development with pro-active contribution of farmer organizations.

The position adopted by these organizations reflected concerns about a situation that could potentially lead to policy and research agenda that would drive the future in directions that they did not wish for. Indeed, a substantial amount of knowledge from the literature of Futures Studies supports this concern. There is evidence that the capacity to engage in forward thinking, and turn the knowledge generated into actions, determines the future. De Jouvenel (2004), for example, considered that the particular view a dominant group in a nation has about the future, determines how the future of the nation unfolds. In their study on food scenarios van Dijk and Meijerink (2014) show that the scenarios are determined by the nature of the causal models. It has been argued that the global foresight work of the international community and advanced countries, in particular the UN Food and Agriculture Organization Outlooks (Alexandratos and Bruinsma, 2012), shapes the global research and development agenda (Grethe et al., 2011; Tomlinson, 2013), affecting the lives of millions of people worldwide who are not in a situation to discuss its content (Jhirad et al., 2009).

From a theoretical point of view, the situation described in the inventory showing that Futures Studies on food, agriculture and rural development mainly focus on food security, rely on projections and quantitative analysis and are performed by institutions of advanced economies that are closely related with centers of global political influence such as the World Bank, FAO, G8 and G20, echoes with what some authors have called "mode 1 foresight" (Da Costa et al., 2003). In mode 1 foresight the use of the future supports the existing system through incremental improvement or optimization. In this mode Futures Studies are essentially conducted with a policy/decision making objectives. Futures Studies become an "implicit instrument of governance" whose purpose is more about reaching " $a$ consensus around certain pre-determined policy perceptions than the genuine search for alternatives" (Ahlqvist and Rhisiart, 2015, p. 102). The persistent focus of most futures studies over the last 15 years on food security and productivity witnesses such pre-determined perceptions. The way the future is approached regarding food, agriculture and rural development can also be seen as a "model monopoly" with universal application. In a model monopoly, a group of initiated people understand the model and others have either to accept it or fight it (Ramos, 2010). This model monopoly can potentially create an "attractor state" in the sense that it could prevent from alternative future development paths to exist outside the pre-determined perceptions on which the future is explored (Derbyshire, 2016). It would then result in a lock-in situation as described by (Wilkinson et al., 2013), where in this case the future properties of the food, agriculture and rural development system become endogenously fixed.

The approach proposed here intended to respond to the legitimate concerns of GFAR constituencies, taking into consideration the practical implications of its conceptual formulation, and to prevent a situation where a model monopoly could potentially become the expression of "specialised self-referential systems of thought veering into ideology" (Ramos, 2010, p. 117). 
The theoretical legitimization of the approach is that participatory action research grounded on integrative rather than integral futures has the capacity to balance the determinism of this "mode 1 foresight" with choice based on human agency and the responsibility to build the future we want (Derbyshire, 2016), inducing the emergence of a mode 2 foresight (Da Costa et al., 2003) where fundamental changes in the system can be discussed, promoted and implemented through the inclusion of new actors. It sought to impulse a bottom-up transition path that is empowerment dominated as identified by (De Haan and Rotmans, 2011), by introducing diversity as a means to disengage from such a potential lock-in situation that could keep the future of food, agriculture and rural development into a path dependent trajectory that will deprive most of the actors from the capacity to engage on shaping the future they want (Könnölä et al., 2007). In short, the intent is to move from a merely utilitarian dimension of Futures Studies to an emancipatory dimension (Ahlqvist and Rhisiart, 2015).

The initiative presented and discussed in this paper intends to address the research question through an endeavor to develop local communities' "futures literacy" as a capacity to sense and make sense of the present (Miller, 2015; Poli, 2015) through a learning-bydoing process. The methodology relies on participatory action research where local community organizations engage in, and use future thinking as producers of foreknowledge to reflect, and potentially act, on their own futures. The paper presents and discuss three cases. However, it does not intend to conduct a comparative study across the three cases as local-specific contexts would make generalization through comparison highly disputable. The heuristic dimension of the cases rests on the provision of practical experiences and understanding on how futures literacy can be built at grassroots level and eventually used for agency.

In Section 2 we first presents the research framework on which this approach was built, connecting the use of the future, scenario planning, empowerment, capability and action research. This framework serves then as a reference to characterize the main features of PPA and the research methodology.

Section 3 describes the research context and the implementation of the three cases in India, Indonesia and the Philippines.

In Section 4 we present evidence of the emergence of futures literacy as an empowerment process connected to local agency and societal transformation.

Section 5 focuses on what makes the use of the future empowering in the PPA approach. We discuss the contribution of co-elaborative scenario building to empowerment as a learning experience which enables local stakeholders to use the future to sense, and make sense of the present and open new opportunities. 


\section{Research framework: scenario planning, empowerment and action research}

\subsection{Connecting the future, scenarios, empowerment and action research}

Special issues of major journals in the field of Futures Studies (including this Journal's 2010 special Issue on Strategic Foresight, its 2013 issue on Scenario methods and this Issue) and other dedicated articles have largely documented the use of scenarios. Scenarios in Futures Studies are amongst the most common and widely used methods (Popper, 2009). They are regularly acknowledged both as mental models and as methods permitting the exploration of the future (Ringland, 2010), supporting the posture of many futurists for whom using the future has two values, its content and its process (Mermet, 2009); the "what" and the "how" (Gertler and Wolfe, 2004). They contribute to using the future to both generate information and stimulate action (Bootz, 2010; De Smedt et al., 2013; Özkaynak and Rodríguez-Labajos, 2010).

Scenario planning has not only gained momentum in the literature (Varum and Melo, 2010), it has also been increasingly used in practice (Amer et al., 2013). There is also growing recognition about using scenarios not for predictive purposes (Amer et al., 2013; Burt and Wright, 2006; Curry and Schultz, 2009; Fortes et al., 2015; Harries, 2003; Inayatullah, 1998; Kok et al., 2006b; Neugarten, 2006; Pourezzat et al., 2008; Wodak and Neale, 2015), but as "an aid to anticipation of the future under conditions of low predictability" (Wright and Goodwin, 2009).

\subsubsection{Diversity in scenario planning}

Influential reviews of Futures Studies literature witness the diversity of concepts and practices related with scenario planning. Authors have developed typologies according to specific entry points or questions. van Notten et al. (2003) designed a scenario cartwheel representing a typology of scenarios built from three themes: project goal (why?), process design (how?) and scenario content (what?). Using a historical approach Bradfield et al. (2005) proposed a typology of scenario techniques referring to three different schools, the Intuitive Logics, the Probabilistic Modified Trends and La Prospective. After reviewing existing typologies Börjeson et al. (2006) developed their own typology based on a user perspective differentiating predictive, explorative and normative scenarios. They also introduced the notion of external versus strategic (internal) scenarios within the explorative group. Wilkinson et al. (2013) re-visited these typologies and their connection to complexity. Amer et al. (2013) review the scenario planning literature, comparing the three schools of scenario techniques and highlight two major issues for successful scenario planning: the combination of quantitative and qualitative techniques leading to more robust scenarios and the importance of consistency and plausibility.

\subsubsection{From scenario to action}

Turning the use of the future through scenario planning into action is not much documented by field evidence (Cairns et al. 2017, this issue) and remains a recurrent issue for foresight practitioners. While in the field of strategic foresight for private companies or public 
organizations one would argue that it is a matter of support and commitment from the highest levels of the hierarchy (Bezold, 2010; Nelson, 2010), in less structured environments, where no such hierarchy prevails, moving from anticipation to action remains a challenge. In this paper, we focus on the latter situation, using the future and scenarios in multi-stakeholder, multi-organizational contexts, dealing with "wicked problems" characterized as "social system problems which are ill-formulated, where the information is confusing, where there are many clients and decision makers with conflicting values, and where the ramifications in the whole system are thoroughly confusing" (Churchman, 1967, p. B-141). Our postulate is that, in such situation, the path from anticipation to action requires an intermediary step, that is, empowerment.

\subsubsection{Empowerment}

Scenario practitioners seldom define explicitly empowerment. Most of the literature that associates scenario planning with empowerment refers to participation aiming at the appropriation of the scenarios (Reed et al., 2013). Participation (and rigor) is recommended when scenarios are used to mobilize collective intelligence and to face a rapidly evolving external environment (Durance and Godet, 2010). Participatory processes are expected to empower people to have influence on policy (Sisto et al., 2016).

For Vervoort et al. (2015), however, empowerment lies in the capacity of societal actors engaged in scenario building to create or reshape the future rather than to adapt to futures pre-defined by others. We share this posture and offer and use here a definition of empowerment in relation with the use of the future and scenarios as follows:

"Empowerment is a process aiming at developing the capacity to use the future and by its usage to self-determine it". Empowerment is a capacity, not an action by itself. The occurrence of empowerment would therefore not be measured by actions that should be connected to a scenario planning process, but by the capacity acquired in using the future. Poli (2015) argues that while the capability approach developed by Sen and Nussbaum does not explicitly refer to a future orientation, making the latter explicit provides new directions for the use of the future, in particular the capacity for individual and organization to choose explicitly between different futures. Building upon this argument, we consider empowerment as a pattern of societal transition leading to the emergence of a new form of organized power, or constellation, within a society (De Haan and Rotmans, 2011). In this context, empowerment is also about the emergence of local organizations as key players in a societal transition shaped by an understanding of future challenges from a diversity of perspectives (bottom-up constellation change).

Empowerment is thus about developing futures literacy as a capability (Miller, 2007), a capability of sensing and sense making (Miller, 2015). It is a prior step before potentially leading to an "external capability" (Krawczyk and Slaughter, 2010), the latter being "the capability of local actors to pursue their own objectives and influence a given situation; namely, local agency" (Özkaynak and Rodríguez-Labajos, 2010, p. 998). External capability or local agency reflects the possibility for future-literate local communities to use the future for action. While local agency requires the type of futures literacy that scenario planning can bring, it does not automatically derive from the use of scenario; it is context-dependent and shaped by existing institutional arrangements, particularly when facing complex power 
relationships (Cairns et al., 2017) that characterized wicked problems in multi-stakeholder context.

For empowerment as the emergence of a futures literacy to lead to local agency in a multistakeholder, inter-organisational context, a very specific type of participation is needed, a co-creation, defined as "a generative process where ideas, opportunities and aspirations are studied by very different stakeholders in an interactive re-invention mode" (quoted by Wilkinson et al., 2014, p. 5).

Finally, making the use of the future an empowerment process requires an action research posture as defined by Ramos (2006) with five characteristics: it aims at improving the human condition, it is participatory, it is heuristic, it is research by participants for participants and it has "a democratic ethos" (p644). Ramos (2006), p. 649) identifies three levels of practice where a confluence between action research and future studies can be observed, namely the "first person" (transpersonal and educational) the "second person" (community and organizational) and the "third person" (inter-organisational and subpolitical).

\subsection{Participatory Prospective Analysis: co-elaborative scenario building for empowerment}

The above review provides a framework of concepts, principles and features against which the PPA approach can be characterised as a scenario planning method. In this approach, we define a scenario as: "A description of how the future may unfold according to an explicit, coherent and internally consistent set of assumptions about key relationships and driving forces"(GFAR, 2014). Foresight is defined as: "A systematic, participatory and multi-disciplinary approach to explore mid- to long-term futures and drivers of change" (GFAR, 2014). These definitions reflect the conception of scenarios as both tools for exploring the future and a new attitude (Bootz, 2010).

Table 1 displays the characteristics of the PPA approach with reference to the concepts, principles and main features used to characterize scenario planning as per the literature review in Section 2.1.

Table 1. Relating the PPA approach to scenario planning concepts and practices.

\section{Concept/practice (with references) \\ Project goal}

Process design

Scenario content

\section{Characteristics of PPA}

Descriptive and exploratory scenarios; issue- and area-based Usually mid-term range (10-25 years) and local scale Quantitative and qualitative; data generation through co-creation, supported/complemented by desk work Funded by international community and/or donors/projects; sometimes with contribution from local organizations Usually open institutional conditions Start with snap-shot then developmental; heterogeneous variables Combination of trend and alternative, peripheral (discontinuity) scenarios; discontinuity is systematically integrated in the exploration of future states of the drivers and in the identification of plausible contrasted scenarios; high level of 


\section{Concept/practice (with references)}

Reference: (van Notten integration (trans-disciplinary) et al., 2003)

Scenario techniques

Reference: (Bradfield et al., 2005)

User's perspective

Reference: (Börjeson et al., 2006)

Scenario building Method and principles Number of scenarios

Source: (Amer et al., 2013)

Type of research Reference: (Ramos, Implementation by trained local resource persons as facilitators and local actors as
2006)

Scale

Reference: (Özkaynak and Rodríguez-

Labajos, 2010)

\section{Characteristics of PPA}

Based on La Prospective, it can also be seen as a hybrid of the plausibility-based intuitive logics scenario development methodology (Wright et al., 2013) and the probability/ preference-based "futuribles" of La Prospective (De Jouvenel, 2004; Godet, 2010)

Explorative and then normative Internal (strategic) scenarios (Chermack, 2004). Scenarios as intermediary boundary objects serving in a decision making process involving social choices (Jungcurt, 2013)

Combine quantitative and qualitative methods

Consistency and plausibility; Rigor and participation (Durance and Godet, 2010) Not pre-defined by the method as for example the four scenarios of the $2 \times 2$ matrix of the intuitive logics school (Curry and Schultz, 2009). Authors recommend "An organization should avoid building more scenarios than it can use" (Ramirez and Wilkinson, 2014: 258). The number of scenarios that can be used in the context of the application of PPA is high, usually above five.

Action research lead by participants for the participants, with a democratic ethos, at the convergence of "first person" and "second person"

Anticipatory action learning in the sense that it "is goal-creating, where goals are selected and created during the process and not preordained by an external authority"

Locally made scenarios rather than adapting global scenarios

In summary, the PPA approach is adapted from French school of "La prospective" (Godet, $1986,2010)$. It focuses on the use of scenarios at local level for - and by - local stakeholders. Its objectives thus differ from the exploration of external environments for large corporations or public entities (Durance and Godet, 2010; Vecchiato and Roveda, 2010). An essential element is that the "client" is not a consumer of futures, but a "doer", a producer of future. Developing scenario aims at helping these doers to think about the future (Coates et al., 2010). The use of the future and scenarios has two connected dimensions, providing local actors with i) the skills to generate their own scenarios and explore the future - a capability development dimension, and ii) the possibility to become pro-active (Godet, 2010), - an empowerment dimension. Plausibility prevails over probability, for the reason that, beyond the criticism of probabilities in scenario building (Miller, 2007), in this approach, estimating the probability of occurrence of different scenarios is hindered by i) a high degree of uncertainty due to the granularity of the analysis, and ii) the potential for local agency that would directly affect the likelihood of the scenarios. 
The technical sequence of the co-elaborative scenario building approach entails the following elements (see also Fig. 1):

- Definition of the system (what?; where?; how long?; who?)

- Identification and definition of the of change affecting the system (past, present and future)

- Cross-impact analysis of mutual influence and structural matrix

- Visualization and selection of key drivers

- Exploration of the future states of the key drivers and analysis of incompatibilities (m orphological analysis)

- Building and selection of contrasted mutually exclusive scenarios

- Development of scenarios ("worldmaking")

- Connecting scenarios to potential actions (through discussion or/and backcasting)

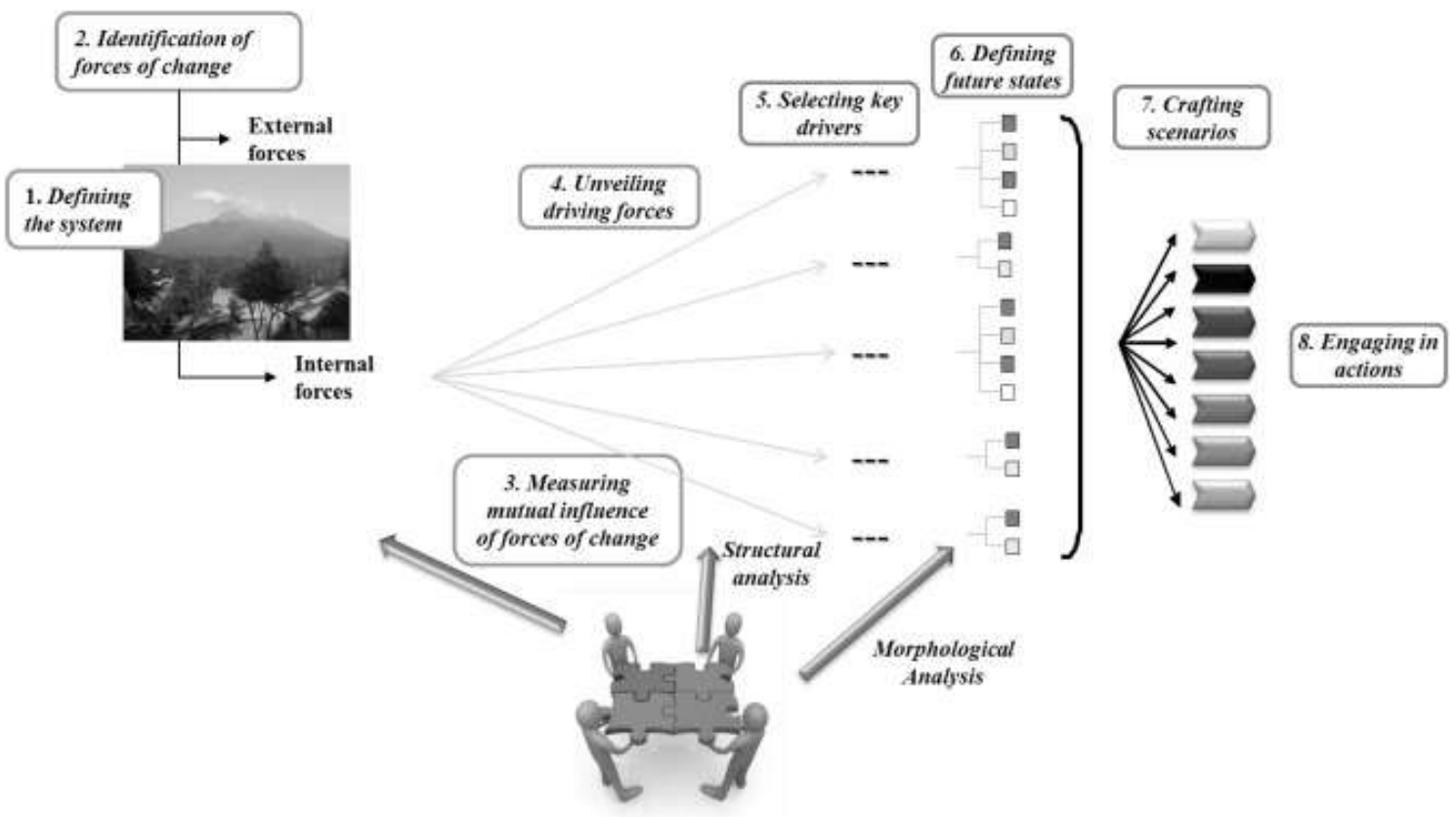

Fig. 1. The technical steps and the sequence of the co-elaborative scenario building process in the PPA approach.

Supporting this technical sequence, a procedural dimension combines a co-construction process where each participant provides part of the knowledge needed and contributes to the gradual elaboration of the scenarios, with a form of contradictory confrontation, where disagreements are discussed and regulated through an agreed-upon rule of acquiescence (Laffont, 2012). The whole process requires also trained resource persons, a careful selection of the participants relying on specific principles and personality traits $^{3}$, and their continuous presence throughout the whole process.

\subsection{Research methodology}

The field work reported here was implemented in accordance with the principles of action research, particularly, participation, research by the participants for the participants, with a 
heuristic dimension. The main author of this paper assisted AFA and the local organizations in acquiring the necessary skills for field implementation (see Section 3.1).

The co-authors of this paper supervised and/or implemented the field work. Information resulting from field implementation (identification of the system, forces of change, driving forces and their future states, scenarios, action plan, quotes and concrete actions) was locally collected by the local facilitators. The format for collecting information was common to all cases and designed to record the intermediary products generated: the formulation of the system, the list of the forces of change and their definition, the influence/dependence matrix, the visualization graphs, the selected drivers and their future states using a morphological table, the synopses of the scenarios and their narratives, quotes recorded during the field work and elements of action derived from the foresight activities.

Data and information generated during the scenario building sessions were systematically recorded by the trained facilitators (see Section 3.1) as these were needed both as intermediary results and as inputs for the next steps. Facilitators kept records of the results using common standard formats for collecting all outputs. These data collection forms included: a formal definition of the system, the comprehensive list of the driving forces and their exact definition, the influence/dependence matrix, the "motricity" graphs, the list of the selected forces used to build the synopsis of the scenarios, the morphological table of future states for all selected forces, the list of mutual incompatibility across the different states and the related spreadsheet enabling a direct screening of proposed scenarios, the list of proposed scenarios with their key features, and the scenario narratives. All these elements formed a coherent system of self-validation by facilitators and participants during the scenario workshops as well as a comprehensive framework for checking and supervision by AFA supervisor and the co-authors. All results were included in field implementation reports by the facilitators and sent to AFA for supervision and control. The reports were cross-checked through interactions between the co-authors of this paper, with several iterations. These interactions took place through virtual and face to face meetings where questions regarding results and processes were discussed. The AFA supervisor consolidated the reports into an integrated document, annexing detailed case study reports including results as well as institutional arrangements made for the implementation of these cases.

Case study reports, AFA report, and direct interaction with the facilitators and supervisors are thus the main sources of data for this paper. The material for the discussion of empowerment was collected ex post from the reports and from the local records of the sessions by the co-authors and discussed in the light of framework presented in Section 2.1.

\section{Research context: the Asian Farmer Association and the case studies}

\subsection{Preparing for local implementation}

The three case studies were developed upon the request of the Asian Farmer Associations, one of the GFAR constituencies. The Asian Farmers Association for Sustainable Rural Development (AFA) is a regional alliance of national farmers' organizations, with 17 members in 13 countries and a membership of around 12 million small-scale women and men farmers, fishers and indigenous people. 
AFA signed a Letter of Agreement with GFAR for implementing the grassroots foresight initiative in Asia with technical and financial support from GFAR. AFA coordinated its implementation. GFAR, through FAO, supported the cost of the initiative for an amount of USD $\$ 53,000.00$, provided by the European Commission. AFA managed funds and provided supervision accordingly. AFA and the local partner organizations also contributed with significant in-kind resources, mainly staff time and facilities.

AFA identified three local volunteer organizations through internal consultation with its own constituencies and signed partnership local agreements with them.

A capacity-building event was first organized by AFA in the Philippines before the start of the field work. Its purpose was to train local resource persons from the selected organizations as facilitators of the co-elaborative scenario building approach. The six-day event operated as a learning-by-doing process where participants acquired the technical know-ledge needed for the implementation of the PPA approach at local level (as indicated in the technical sequence in Section 2.2), and the know-how required to facilitate local implementation. Eight people attended and completed the training (two from Indonesia, three from the Philippines including AFA Executive Secretary, three from India and two from AFA). They were selected by AFA and the partner organizations among their professional staff at local level. Selection was based on profile specifications included in the methodology regarding the role of the facilitators. Facilitators' profiles and roles are briefly described in Appendix 1 (available online).

The workshop included an introduction to the grassroots foresight initiative and methodlogical sessions intertwined with practical consideration regarding facilitation. All participants learned how to use and facilitate the PPA approach, working through all steps, from the identification of the system to the building of scenarios and their follow-up. They brought home hard and electronic copies of the training material ${ }^{4}$. The training material was available in English and Indonesian. It was then locally translated in Hindi, Tagalog and the local muhan and krowin languages of the Boru community.

\subsection{Local field contexts}

In India, the Institute of Himalayan Environmental Research and Education (INHERE), a local NGO, managed the work. INHERE is based in the Almora District, in the Uttarakhand State in north India, where the selected area of Kumaon and Garhwal administrative divisions are located. The INHERE facilitators were both involved in agricultural programs with mountain farmers. An INHERE Advisor oversaw the implementation of the local activities.

In Indonesia, Aliansi Petani Indonesia (API), a national farmer organization, managed the implementation of the initiative through its East Nusa Tenggara Province (NTT) chapter. The selected area was the Boru community territory in the centre of Flores Island in NTT. Two facilitators from API's chapter in NTT implemented the activities, both from the Boru community.

In the Philippines, PAKISAMA, a national farmer organization managed the initiative. The selected area included the towns of Balabac and Bataraza in the southern part of Palawan 
Island. One facilitator from PAKISAMA and one from SAMBILOG, a local affiliate composed mainly of Palawan indigenous group, implemented the field work.

Table 2 below presents the characteristics of each area and their local context.

Table 2. Main characteristics of the three locations where the foresight initiative took place.

\begin{tabular}{|c|c|c|c|}
\hline & India & Indonesia & Philippines \\
\hline $\begin{array}{l}\text { Location of the } \\
\text { field work }\end{array}$ & $\begin{array}{l}\text { Kumaon and Garhwal } \\
\text { divisions, Uttarakhand, India }\end{array}$ & $\begin{array}{l}\text { Boru community, Flores } \\
\text { island (NTT) }\end{array}$ & $\begin{array}{l}\text { Municipalities of Balabac and } \\
\text { Bataraza, southern part of } \\
\text { Palawan Island }\end{array}$ \\
\hline $\begin{array}{l}\text { Characteristics } \\
\text { of the area }\end{array}$ & $\begin{array}{l}53,000 \mathrm{~km}^{2} ;>10 \text { million } \\
\text { people; southern slope of the } \\
\text { middle Himalaya range, } \\
\text { forested; Climate: temperate } \\
\text { to subtropical }\end{array}$ & $\begin{array}{l}90 \mathrm{~km}^{2} ;>3000 \text { people; } \\
\text { volcanic slopes of a semi- } \\
\text { arid island } \\
\text { Climate: semi-arid }\end{array}$ & $\begin{array}{l}1300 \mathrm{~km}^{2} ;>100,000 \text { people; } \\
\text { southernmost tip of Palawan } \\
\text { Island, coastal area and small } \\
\text { islands } \\
\text { Climate: tropical }\end{array}$ \\
\hline $\begin{array}{l}\text { Local context of } \\
\text { the foresight } \\
\text { initiative }\end{array}$ & $\begin{array}{l}\text { Smallholder farmers in the } \\
\text { region are demoralized. Mass } \\
\text { diversion from agriculture to } \\
\text { other occupations leaves } \\
\text { agricultural land barren in the } \\
\text { villages. Remaining farmers } \\
\text { struggle against climatic and } \\
\text { other adverse conditions }\end{array}$ & $\begin{array}{l}\text { The leaders fear that the } \\
\text { unique Boru culture will } \\
\text { disappear with the } \\
\text { onslaught of science and } \\
\text { technology. Local } \\
\text { communities experience } \\
\text { internal conflict regarding } \\
\text { access to natural resources }\end{array}$ & $\begin{array}{l}50,000 \text { hectares of ancestral } \\
\text { lands and waters taken from the } \\
\text { local communities by a local } \\
\text { power. Two large corporations in } \\
\text { the south sea pearls and } \\
\text { agriculture business control the } \\
\text { area. Entry to ancestral lands and } \\
\text { waters for the communities is } \\
\text { prohibited. }\end{array}$ \\
\hline
\end{tabular}

Source: AFA report, case study reports, interviews of supervisors.

\section{Results}

This section presents the main results of the implementation of the PPA approach in the three cases. It intends to provide concrete evidence of empowerment according to the three dimensions we highlighted in Section 2.1: futures literacy as a capacity to sense and make sense of the present; a potential for local agency, and a process of societal transformation.

\subsection{Futures literacy}

The acquisition of futures literacy as the capacity to use the future to sense and make sense of the present is a manifest result of the implementation of the PPA approach in the three cases. Table 3 displays the activities undertaken and the results obtained by each local organization regarding the preparation and implementation of the work at local level. It demonstrates first that the facilitators trained at the capacity-building workshop were able to use the technical knowledge and the facilitating skills they learned in a training environment and apply them to a real context. Variations in the planning and organization of the field work demonstrate their understanding and sensing of the approach. Each organization adjusted the format of the scenario building process in accordance with feasibility in the field. In India, INHERE organized a series of internal preparatory workshops to ensure the development of a critical mass of competences and organized two workshops for a total of five days, followed by an additional two-day workshop. In Indonesia API 
Table 3. Key results of from the field implementation of the three cases studies.

\begin{tabular}{|c|c|c|c|}
\hline & India & Indonesia & Philippines \\
\hline Preparation & $\begin{array}{l}\text { Two preparatory workshops for } 18 \\
\text { INHERE staff. Material translated into } \\
\text { Hindi }\end{array}$ & $\begin{array}{l}\text { Set criteria for selecting } \\
\text { participants and invited } \\
\text { shortlisted participants }\end{array}$ & $\begin{array}{l}\text { Set criteria for selecting } \\
\text { participants. Shortlist of } 20 \\
\text { participants }\end{array}$ \\
\hline $\begin{array}{l}\text { Workshops } \\
\text { dates }\end{array}$ & $\begin{array}{l}\text { April 18-20, 2015; } \\
\text { October 9-10, 2015 }\end{array}$ & $\begin{array}{l}\text { April 2-May 3, } 2015 \\
\text { June 3-5, } 2015 \\
\text { July 1-3, } 2015\end{array}$ & $\begin{array}{l}\text { April 27-May 1, } 2015 \\
\text { May 11-15, } 2015\end{array}$ \\
\hline Participants & $\begin{array}{l}26 \text { including senior and women } \\
\text { farmers, local government, wise } \\
\text { people associated with agriculture, } \\
\text { researchers, civil servant, local } \\
\text { business people and journalists }\end{array}$ & $\begin{array}{l}21 \text { including Boru indigenous } \\
\text { communities, District } \\
\text { Agriculture and Forest } \\
\text { Departments, Administrator } \\
\text { of District }\end{array}$ & $\begin{array}{l}15 \text { including Sambilog leaders, } \\
\text { local government, NGO and } \\
\text { media }\end{array}$ \\
\hline $\begin{array}{l}\text { Definition of } \\
\text { the system }\end{array}$ & $\begin{array}{l}\text { What could happen to mountain } \\
\text { farmers in } 2025 \text { ? }\end{array}$ & $\begin{array}{l}\text { What could happen to the } \\
\text { culture of Boru in } 2035 ?\end{array}$ & $\begin{array}{l}\text { What could be the state of the } \\
\text { ancestral land and waters of } \\
\text { the Pala'wan and Molbog } \\
\text { tribes together with SAMBILOG } \\
\text { in 2025? }\end{array}$ \\
\hline $\begin{array}{l}\text { Forces of } \\
\text { change }\end{array}$ & 46 & 40 & 35 \\
\hline $\begin{array}{l}\text { Internal } \\
\text { forces }\end{array}$ & 23 forces used in structural analysis & $\begin{array}{l}40 \text { forces; no structural } \\
\text { analysis }\end{array}$ & $\begin{array}{l}33 \text { forces used in structural } \\
\text { analysis }\end{array}$ \\
\hline Driving forces & $\begin{array}{l}5 \text { forces: } \\
\text { - Farmer organization } \\
\text { - Improved varieties with diversity } \\
\text { - Technical knowledge and } \\
\text { communication } \\
\text { - Price of the produce } \\
\text { - Youth in agriculture }\end{array}$ & $\begin{array}{l}9 \text { forces: } \\
\text { - Boru culture } \\
\text { - Governance and democracy } \\
\text { - Rites and rituals } \\
\text { - Education } \\
\text { - Community health } \\
\text { - Spirituality and forest } \\
\text { management } \\
\text { - Traditional institutions } \\
\text { - Youth in agriculture } \\
\text { - Economic development }\end{array}$ & $\begin{array}{l}5 \text { forces: } \\
\text { - Government will } \\
\text { - Presence of private } \\
\text { corporations } \\
\text { - Capacity of local } \\
\text { organizations to implement } \\
\text { their plans and programs } \\
\text { - Relationship of Sambilog with } \\
\text { local government } \\
\text { - Availability of infrastructure } \\
\text { in the area }\end{array}$ \\
\hline & $\begin{array}{l}\text { Four scenarios: } \\
\text { S1: farmers organized and in the } \\
\text { forefront (see Table 5) }\end{array}$ & $\begin{array}{l}\text { Thirty scenarios (one per } \\
\text { participant) merged into six } \\
\text { scenarios developed from a } \\
\text { key state of one of the driving } \\
\text { forces } \\
\text { S1: Acculturation }\end{array}$ & $\begin{array}{l}\text { Five scenarios } \\
\text { S1: heightened conflict } \\
\text { between SAMBILOG and } \\
\text { corporate companies } \\
\text { S2: SAMBILOG area dragged } \\
\text { into war between China and } \\
\text { the Philippine over ownership } \\
\text { and access to the West }\end{array}$ \\
\hline Scenarios & $\begin{array}{l}\text { S2: farmers struggling and doing what } \\
\text { they can } \\
\text { S3: farming for the young and smart } \\
\text { S4: farming communities see their end }\end{array}$ & $\begin{array}{l}\text { S2: Economic divide } \\
\text { S3: Loss of traditional } \\
\text { governance } \\
\text { S4: Prevalence of traditional } \\
\text { institution } \\
\text { S5: Youth in agriculture } \\
\text { S6: (see Table 5) }\end{array}$ & $\begin{array}{l}\text { Philippines Sea } \\
\text { S3: chaos, high crime rates, } \\
\text { breakdown of peace and order, } \\
\text { beyond the control of the } \\
\text { authorities } \\
\text { S4: Top-down Government } \\
\text { projects without involvement } \\
\text { of local organizations } \\
\text { S5: (see Table 5) }\end{array}$ \\
\hline
\end{tabular}


Note: Results from the Boru community are reported after translation from the two local Krowin and Muhan languages into Bahasa Indonesia and then into English.

Source: AFA Internal Final report.

The participants engaged in these workshops demonstrated a capacity to explore the future as witnessed by the number and the diversity of the internal forces of change. They identified respectively 23, 40 and 33 internal forces in India, Indonesia and the Philippines. Table 4 displays the selected driving forces across a Social, Technical, Economic, Environmental, Political (STEEP) classification (Slaughter, 2008). These forces are quite evenly spread across all dimensions demonstrating a capacity to explore the future beyond the knowledge boundaries of the participants.

Table 4. Distribution of driving forces according to the STEEP categories.

\begin{tabular}{cl} 
Driving forces & \multicolumn{1}{c}{ India } \\
Social & Youth in agriculture \\
Technical & $\begin{array}{l}\text { Technical knowledge and } \\
\text { communication; Improved } \\
\text { varieties in diversity }\end{array}$ \\
Economic & Price of the products
\end{tabular}

Environmental

Policy Farmer organization
Indonesia

Boru spirituality and illegal cutting of forests; traditional institute; youth in agriculture

Health of community (traditional medicine)

Economic development

Natural resources

\section{Philippines}

Relationship of Sambilog with local government

Availability of infrastructure in the area

Presence of private companies in the area

Capacity of local organizations to implement their plans and programs; Government will

Source: based on AFA report.

Sensing was also at the core of the exploration of alternative states for the driving forces. Using a facilitation technique helping them to focus on desirable, undesirable, trend and rupture states the participants acquired a capacity to anticipate and explore a diversity of future situations.

The capacity to make sense of their exploration of the future is witnessed by several outputs. First, as a result of structural analysis applied in India and the Philippines, five driving forces were identified and selected due to their role in the systems they discussed. In Indonesia, they identified nine driving forces through a different process of alternate working groups and plenary conversations. The reason was that the resource persons felt that structural analysis was going to be complicated with a risk of demotivating the participants, having to use three languages, Indonesian and the local krowin and muhan languages.

A manifest product of the capacity acquired by the participants was the creation of contrasted scenarios (Table ...). In Indonesia and the Philippines scenarios resulted from the combination of futures states of the driving forces into plausible representations of the future, using the same facilitation technique as for exploring future states. In India, INHERE 
reported that "Some participants felt that the states could have been different and other scenarios were possible with different combinations, so they made changes and after the workshop was over in the following days worked on it to create more scenarios". In Indonesia, an interesting adaptation required by the absence of structural analysis was made as each of the 30 participants was given the task to build one scenario. The difference and similarity of the scenarios was then discussed collectively and led to regroup them into six contrasted scenarios.

The capacity to use the future was a new experience for the participants. In India, AFA reported that all the participants found the scenario-building workshop very engaging and were interested in the new technique. AFA quoted the INHERE supervisor as follows: "It was truly a great experience to see diverse people come together and think about their likely common future. Many of the participants said they had not experienced anything like this ever."

It has been argued that "to articulate the futures we do not want may paradoxically be just as important as articulating those we want" (Karlsson, 2005, p. 1101). In India, the S4 scenario (see Table 2, Section 3.3) jolted people as it was a plausible reality. It spurred thinking on what could and should be done and drove people to explore what they should do to move towards the preferred scenario. AFA reported that in the Philippines, some scenarios represented different plausible futures that the participants feared. Participants indicated that doing this foresight work opened everyone up to the reality that "plans do not always go your way". They valued immersing themselves in the undesirable futures and thinking of ways to delve away from it, corroborating the importance of "dystopia" or negative visions, as these also provide useful fore-knowledge for normative decisions and societal choices.

\subsection{Potential for local agency}

In Section 2.1 we considered also the capacity to use the future to snese and male sense of the present as a potential for engaging in action, as a capability for local agency. The three cases provide premises of the emergence of such potential.

Firstly, all cases progressed from an exploratory phase of sensing and sense making which produced the scenarios to a normative phase where a preferred future represented by the scenario considered as the most desirable was identified. These scenarios are presented in Table 5.

Table 5. Preferred scenarios as identified by the participants.

Location

Preferred scenario

Farmers organize at village level with apex representation at the national level. At all levels farmer representatives are active in securing opportunities and favorable plans, decisions and support, influencing policy making and programs. Young people view agriculture as an enterprise and livelihood through which they can fulfill their aspirations. In the villages, they create multiple streams of income through agro-based activities and other opportunities. They earn good income from agriculture using innovations, along with valuable traditional agricultural knowledge. Farmers develop strong marketing linkages and sell their products at a good price, creating value chains for better returns. Technical agriculture knowledge and information is timely, available and benefits 
farmers. Improved and good quality seeds of all local crops are locally available and farmers conserve the biodiversity. Agricultural biodiversity ensures hill farmers' food security, nutrition and risk resilience.

Boru indigenous peoples are proud of their culture and identity and promote it among their young.

Indonesia They preserve indigenous governance and leadership systems. They are able to process their natural resources according to their local ability. Young people unite and work together in managing their common natural resources, opting to stay in their communities.

The Pal'wan and Molbog Sambilog member indigenous people have reclaimed their ancestral

Philippines lands and water. Local fisher folk communities in the area have regained access to municipal waters. Sambilog is implementing programs/projects with government support. Peace and progress prevail in the area.

Source: AFA Final report.

All scenarios describe positive futures that are the products of local agency by the local communities. These positive futures do not result from favorable contexts or contingent events, or projection of current trends. They are all built on discontinuities created by the agency of local stakeholders. As such they constitute a linking element in the continuum between the acquisition of the capacity to use the future to sense and make sense of the present (futures literacy) and actions.

The potential for local agency appears also in the discussions that followed the selection of a preferred scenario. Table 6 displays the immediate actions the local communities identified in connection to these scenarios.

Table 6. Immediate actions identified by the participants after completion of the co-elaboration of scenarios.

Build and strengthen farmers' capacities to form and manage their own organizations so that these give effective services to their members and can influence decision makers.

Create interest and attract youth to family agriculture using labor reducing tools and productivity

increasing technology, multiple income streams with higher value, reduce risks in agriculture, support youth in agriculture.

Training and support to increase income of farmers.

Enable access to newer technology, equipment and support services;

Access to good quality seed of diverse crops and varieties.

Establish an institute that promotes the Boru culture.

Indonesia Build capacities of the Boru community to process their natural resources in local and sustainable ways that can also earn incomes for them.

Establish young farmers organization in Boru community

Further strengthen Sambilog and build capacity of its leaders and local community organizers.

Access funds for economic activities (e.g., seaweed farming, value addition of coconut) of affiliated

Philippines members.

Continue current work to return lands taken away to their original owners or their descendants.

Make the municipal waters accessible again to local fishers

Source: AFA report and personal communication with local supervisors. 


\subsection{Societal transformation}

Another manifestation of empowerment is the societal transformation process that the capability to use the future to sense and make sense of the present, and turning it into a potential for local agency has locally initiated. This process is characterized by the emergence of bottom-up power constellations. In India, INHERE objectives as per the preferred scenario is to support farmers to build and strengthen their own organizations so that they will be in a situation to face the administrative and economic power of the ruling public and private elites. In Indonesia, the Boru community intends to establish a unified institution that will promote and support the Boru culture. Until now the Boru community was split into at least two sub-groups in two different villages who used to fight another for access to forest land, and other natural resources. In the Philippines, SAMBILOG has prioritized its strengthening by enlarging membership to other community members, and focuses on building the capacity of local leaders and community organizers.

While it is too early for a thorough assessment of evidence, local actions have already taken place witnessing the emergence of these local organizations as key players in a societal transition shaped by the understanding of future challenges. In India, farmers at village level as well as with stakeholders in agriculture are discussing the major drivers identified. INHERE carried out a foresight workshop with 25 young farmers (12 women and 13 men) from 10 villages. They developed three scenarios and engaged in thinking at a deeper level about their situation, its causes, and what was within their control. The leaders of the Boru Indigenous Community met with the Forestry Ministry and API pursued dialogue with district agriculture and forestry officials. As a result, forest authorities reclassified the Boru forest area from state forest to community forest, providing the local community more rights in forest management. Sambilog expanded its membership through the recruitment of groups of farmers from the municipality of El Nido, whose leaders attended the grassroots foresight workshop. It also started a cooperative on seaweed production and trading with technical support from the local fisheries bureau.

\section{Lessons learnt and limits}

The question we discuss in this section in the light of the results of the grassroots foresight initiative is: What makes using the future empowering in this approach? Is it merely its participatory nature or something intrinsic to it, beyond the participatory dimension? We also reflect on the limits of the approach.

Development literature largely recognizes the connection between empowerment and participation, the latter enabling people to gain greater ownership and feel responsible for the process and outcome (Patel et al., 2007). Our field work supports the observation that the scenario techniques themselves constitute a crucial element in fostering the selforganization and empowerment of stakeholders (Plieninger et al., 2013; Wollenberg et al., 2000). Two core aspects of the scenario building methodology we used seem to be fundamental elements of the empowerment process as defined in this paper: i) the focus on internal factors and related strategic (internal) scenarios and its local scale and ii) the deliberate devolution of the leading role to local organizations along the principles of action research. 


\subsection{Focusing on internal forces and local scales}

The literature on internal drivers and scenario as a source of empowerment is not very developed. While Börjeson et al. (2006) recognize the co-existence of internal and external factors their review shows that internal factors are at best combined with external factors. It is a particular aspect of La Prospective to acknowledge the co-existence of internal and external forces shaping the future and to treat them differently.

We argue here that focusing on internal forces is a core element of empowerment as defined in this paper. The importance of focusing on internal forces as an empowerment media is reinforced in the PPA approach by a systematic exploration of discontinuities in the future states of the driving forces identified. The driving forces being internal (controllable by the actors of the system), the discontinuities that are unveiled are within the reach of the actors. They become aware that they are in a capacity to influence/transform their system, that they are not powerless, that they are agents of change, at least potentially. Exploring their futures through internal scenarios gives the "doers" the understanding that they can play a pro-active role in shaping the future they wish.

By coupling this focus on internal forces with a local level approach in the design of scenarios, the empowerment process is reinforced. The implementation of the three cases was performed at such a local scale at least in the Philippines and Indonesia. In India, "local" has a different meaning given the size of the country, and though the area was far larger and more populated, implementation by INHERE focused on specific localities in order to build futures literacy. Özkaynak and Rodríguez-Labajos (2010) in their discussion of interactions between larger scale scenarios and local scenarios highlight a local agency dimension as an important dimension of the construction of local scenarios. In their conclusion they indicate that "Due to the enhanced properties of high agency capabilities, the strength of local coalitions with a higher sense of attachment and belonging is likely to enable local interests and values to prevail" (2010, p.1001). We found that statement particularly justified by the evidence provided in Section 4.3.

\subsection{Devolution of leadership to local organizations}

The way co-elaborative scenario building was implemented in the three cases followed the principles of action research by the participants for the participants. The acquisition of technical and facilitation skills by members of the community and their role as initiators and facilitators of the scenario building process changed the perception these local organizations had about their own capacities and the vision other organizations had regarding them.

The lead of the facilitators and local organizations in the initiative and its implementation were concrete examples for all other members and local stakeholders that using the future to sense and make sense of the present was something they could do, since people just like them were able to do it. In addition, during the local workshops the resource persons had to manage skillfully a diversity of participants with different backgrounds and perspectives. They had to build from that diversity a collective wisdom about the future. While there is no direct assessment of a change in the perceptions the other participants had about INHERE, 
SAMBILOG or API-NTT, it makes sense to interpret some actions that followed the field work as products of a change in perceptions. The reclassification of the Boru forest followed interactions between the Ministry of Forestry and leaders of the Boru community witness a recognition by the local administration of new capacities of the local communities. API recently reported that the Boru Kedang Indigenous People Community is now entrusted by the Indonesian Ministry of Forestry and Environment to manage 600 hectares of social forestry area. The expansion of Sambilog membership shows a change in the perception local communities had of Sambilog.

While it is too early to analyze the full impact of the co-elaborative scenario-building process developed in the three cases, it is possible to highlight some additional observations from the field related to this empowerment process. In India, INHERE reported: "We had to deploy a facilitator from INHERE with every small group. We had to take care that the ones with more formal education did not take over because the less educated felt confused and unsure. We found more explanations were needed for women who are less exposed to Hindi, the working language of the workshop, and needed facilitation in their dialects for them to understand and express better". In the Philippines, PAKISAMA reported that "the process was very thorough - the original four day workshop was extended by one day. A postworkshop validation on the workshop results was made a week after with the same participants. The importance of local community organizers in achieving the desired scenario was underscored and acknowledged in the post-validation activity/consultation with the participants".

\subsection{Discussing the limits}

During the implementation of the PPA approach in the three case studies we identified some limitations. These are common to the three cases, and observed elsewhere where the PPA approach is used.

\subsubsection{Time constraint}

Time is a first limit. Building scenario through a co-elaborative process in a multistakeholder, multi-organisational environment, addressing wicked problem, requires time. In India, the INHERE supervisor reported that "However all these [scenarios] have not been translated due to time and expense. Also the four developed at the main workshop were felt to be more sharp, realistic and different so these are the ones retained. The scenarios had also to be refined and articulated more sharply by the resource persons with participation, involvement and agreement of the group. This again was time taking".

This constraint is not only an inherent feature of the approach. It was also due to very limited budget and deadlines, which were finally too short. This is an important lesson, as co-elaborative scenario building requires the involvement of many stakeholders.

\subsubsection{Facilitation and language}

The role facilitators play cannot be underestimated, as witnessed by INHERE who undertook several sessions of internal capacity building before field implementation. There is also a 
contingent dimension linked to the variability of the facilitator's individual characteristics that the best training cannot overcome. Training in facilitation and guidance on the selection of the facilitators from the local partner organizations intended to reduce that risk.

The language barrier is also a constraint. Facilitators had to translated the material from English to Hindi, Tagalog and Bahasa Indonesia and then again into the language of the local communities. In Indonesia the simultaneous use of three different languages affected some of the steps used in the approach. The only remedy we can think of regarding this constraint is taking more time to produce support material.

\subsubsection{Focusing on internal forces}

The third limit is linked to the focus on internal forces and scenarios, which is at the same time a strength of the approach. In the three cases, while some external forces had been identified, they were not further discussed. We are well aware of this limitation which could lead to an over-estimation and over-confidence of the local actors in their capacity to shape their futures, as they do not reflect on external forces beyond their reach that can significantly transform their immediate environment. While, so far, the reflection on external forces and related contextual scenarios is externalized in the PPA method, connecting contextual scenarios and local scenarios is an ongoing work along the lines of reflection and investigation developed by authors interested in scale issues (Kok et al., 2006a; Özkaynak and Rodríguez-Labajos, 2010; Swart et al., 2004; Wilkinson et al., 2013). The perspectives are two include two streams of scenario building in a dialogical mode: one stream of internal scenario building as explained here, and a stream of external scenario building involving expertise that local stakeholders do not have.

\section{Conclusion}

Local communities are rarely empowered to envision, and create, better futures. Learning how to use the future can effectively help communities building powerful shared visions (Jhirad et al., 2009). We provide here empirical evidence of the capacity of co-elaborative scenario building to empower local communities and organizations in the context of food, agriculture and rural development where there is currently a strong imbalance regarding who decides what the futures of local farming and rural communities could or should be and who is affected by these decisions.

We propose Participatory Prospective Analysis (PPA), adapted from La Prospective, as an approach for empowering local actors through the acquisition of futures literacy, based on co-elaborative scenario building. Implementation in three cases in Asia by local farmer/community organizations who engaged in local multi-stakeholder, multiorganizational reflection about their own futures, provided relevant information for discussing empowerment through futures literacy.

The results show that co-elaborative scenario building can empower local communities through a capability approach based on the development of futures literacy seen as a capacity to use the future to sense and make sense of the present, making explicit the anticipatory assumptions of the local actors. It opens possibilities to use this knowledge for 
action, for local agency. We highlighted the importance of focusing the scenario building process on internal forces, at local scale and the devolution of responsibility to lead and manage the process to local community through an action research posture.

What started as a first initiative with a few local communities in Asia will further develop. Three more farmers' organizations, in Central Africa, have already engaged in a similar process. AFA is committed to taking the results of this grassroots foresight initiative to higher levels of decision-making in various international fora. At GCARD3 held in Johannesburg in April 2016, AFA and other farmer organizations associated with this grassroots initiative in Africa committed to engage in a GFAR Collective Action aiming at the re-appropriation of rural futures by the local population. This ongoing initiative witnesses also a feeling of self-confidence of grassroots organization to engage pro-actively in shaping their future also at global level.

Their objective is to advocate for, and make happening, the democratization of the use of the future. This is essential if we want a future created by future-literate, or future-smart, citizens rather than a future resulting from ignorance of the potential that the future holds for us.

\section{Acknowledgements}

This work was funded through financial support provided by the European Commission "European Union contribution agreement with an international organization, number DClFOOD/2013/334/913" to GFAR via FAO. The French Ministry of Foreign Affairs provided support through the assignment of an International Technical Assistant to GFAR. The authors wish to thank Tanya St Georges for her editing work. The author is greatly thankful to the reviewers for their critical comments. They contributed to significantly improve this paper.

\section{References}

Ahlqvist, T., Rhisiart, M., 2015. Emerging pathways for critical futures research: changing contexts and impacts of social theory. Futures 71, 91-104.

http://dx.doi.org/10.1016/j.futures.2015.07.012.

Alexandratos, N., Bruinsma, J., 2012. World Agriculture Towards 2030/2050 the 2012 Revision. ESA Working Paper.

Amer, M., Daim, T.U., Jetter, A., 2013. A review of scenario planning. Futures 46, 23-40. http://dx.doi.org/10.1016/j.futures.2012.10.003.

Bezold, C., 2010. Lessons from using scenarios for strategic foresight. Technol. Forecast. Soc. Chang. 77, 1513-1518. http://dx.doi.org/10.1016/j.techfore.2010.06.012.

Blackman, D.a., Henderson, S., 2004. How foresight creates unforeseen futures: the role of doubting. Futures 36, 253-266. http://dx.doi.org/10.1016/S0016-3287(03)00144-7. 
Bootz, J.P., 2010. Strategic foresight and organizational learning: a survey and critical analysis. Technol. Forecast. Soc. Chang. 77, 1588-1594.

http://dx.doi.org/10.1016/j.techfore.2010.06.015.

Börjeson, L., Höjer, M., Dreborg, K.-H., Ekvall, T., Finnveden, G., 2006. Scenario types and techniques: towards a user's guide. Futures 38, 723-739.

http://dx.doi.org/10.1016/j.futures.2005.12.002.

Bourgeois, R., 2012. The state of foresight in food and agriculture and the roads toward improvement. In: Part 1- Foresight Report to GCARD II - September, 2012. GFAR, Rome, pp. 38.

http://www.fao.org/docs/eims/upload/305471/State_of_foresight_\%20SectionF1_Edited\% 20DO.pdf.

Bradfield, R., Wright, G., Burt, G., Cairns, G., Van Der Heijden, K., 2005. The origins and evolution of scenario techniques in long range business planning. Futures 37 , 795-812. http://dx.doi.org/10.1016/j.futures.2005.01.003.

Burt, G., Wright, G., 2006. "Seeing" for organisational foresight. Futures 38, 887-893. http://dx.doi.org/10.1016/j.futures.2005.12.012.

Chermack, T.J., 2004. Improving decision-making with scenario planning. Futures 36 (3), 295-309. http://dx.doi.org/10.1016/S0016-3287(03)00156-3.

Churchman, C.W., 1967. Free for all. Manag. Sci. 14, B-141-B-146. http://dx.doi.org/10. 1287/mnsc.14.4.B141.

Coates, J., Durance, P., Godet, M., 2010. Strategic foresight issue: introduction. Technol. Forecast. Soc. Chang. 77, 1423-1425. http://dx.doi.org/10.1016/j.techfore.2010.08.001.

Curry, A., Schultz, W., 2009. Roads less travelled: different methods, different futures. J. Futur. Stud. 13, 35-60.

Da Costa, O., Warnke, P., Cagnin, C., Scapolo, F., 2003. The impact of foresight on policy making: insights from the FORLEARN mutual learning process. Tech. Anal. Strat.

Manag. 20, 1-19. http://dx.doi.org/10.1080/09537320802000146.

De Haan, J., Rotmans, J., 2011. Patterns in transitions: understanding complex chains of change. Technol. Forecast. Soc. Chang. 78, 90-102.

http://dx.doi.org/10.1016/j.techfore.2010.10.008. (Hans).

De Jouvenel, H., 2004. Invitation à la prospective, futuribles.

De Smedt, P., Borch, K., Fuller, T., 2013. Future scenarios to inspire innovation. Technol. Forecast. Soc. Chang. 80, 432-443. http://dx.doi.org/10.1016/j.techfore.2012.10.006.

Derbyshire, J., 2016. The implications, challenges and benefits of a complexity-orientated 
Futures Studies. Futures 77, 45-55. http://dx.doi.org/10.1016/j.futures.2016.02. 001.

van Dijk, M., Meijerink, G., 2014. A Review of Global Food Security Scenario and Assessment Studies: Results, Gaps and Research Priorities (No. 20). (FOODSECURE Working Paper. Wageningen).

Durance, P., Godet, M., 2010. Scenario building: uses and abuses. Technol. Forecast. Soc. Chang. 77, 1488-1492. http://dx.doi.org/10.1016/j.techfore.2010.06.007.

Fortes, P., Alvarenga, A., Seixas, J., Rodrigues, S., 2015. Long-term energy scenarios: bridging the gap between socio-economic storylines and energy modeling. Technol. Forecast. Soc. Chang. 91, 161-178. http://dx.doi.org/10.1016/j.techfore.2014.02. 006.

Gertler, M.S., Wolfe, D.A., 2004. Local social knowledge management: community actors, institutions and multilevel governance in regional foresight exercises. Futures 36, 45-65. http://dx.doi.org/10.1016/S0016-3287(03)00139-3.

GFAR, 2014. A Glossary of Terms Commonly Used in Futures Studies [WWW Document]. A Gloss. Terms Commonly Used Futur. Stud.. (URL http://www.fao.org/docs/eims/upload//315972/Glossary of Terms.pdf).

Godet, M., 1986. Introduction to la prospective. Futures 18, 134-157. http://dx.doi.org/10.1016/0016-3287(86)90094-7.

Godet, M., 2010. Future memories. Technol. Forecast. Soc. Chang. 77, 1457-1463. http://dx.doi.org/10.1016/j.techfore.2010.06.008.

Grethe, H., Dembélé, A., Duman, N., 2011. How to Feed the World's Growing Billions: Understanding FAO World Food Projections and Their Implications .

Harries, C., 2003. Correspondence to what? Coherence to what? What is good scenariobased decision making? Technol. Forecast. Soc. Chang. 70, 797-817. http://dx.doi.org/10.1016/S0040-1625(03)00023-4.

Holderness, M., Palmier, H., Strange, R., 2013. GCARD2 conference 2012. Food Sec. 5, 129-134. http://dx.doi.org/10.1007/s12571-012-0234-8.

Inayatullah, S., 1998. Causal layered analysis: poststructuralism as method. Futures 30 , 815-829. http://dx.doi.org/10.1016/S0016-3287(98)00086-X.

Jhirad, D., Juech, C., Michelson, E.S., 2009. Foresight for smart globalization. Foresight 11, 10-13. http://dx.doi.org/10.1108/14636680910982403.

Jungcurt, S., 2013. Taking boundary work seriously: Towards a systemic approach to the analysis of interactions between knowledge production and decision-making on 
sustainable development. In: Transgovernance: Advancing Sustainability

Governance. 9783642280. pp. 255-273. http://dx.doi.org/10.1007/978-3-642-28009-2_7.

Karlsson, R., 2005. Why the far-future matters to democracy today. Futures 37, 1095-1103. http://dx.doi.org/10.1016/j.futures.2005.02.007.

Kok, K., Patel, M., Rothman, D.S., Quaranta, G., 2006a. Multi-scale narratives from an IA perspective: part II. Participatory local scenario development. Futures 38, 285-311. http://dx.doi.org/10.1016/j.futures.2005.07.006.

Kok, K., Rothman, D.S., Patel, M., 2006b. Multi-scale narratives from an IA perspective: part I. European and Mediterranean scenario development. Futures 38, 261-284. http://dx.doi.org/10.1016/j.futures.2005.07.001.

Könnölä, T., Brummer, V., Salo, A., 2007. Diversity in foresight: Insights from the fostering of innovation ideas. Technol. Forecast. Soc. Chang. 74, 608-626. http://dx.doi.org/10.1016/j.techfore.2006.11.003.

Krawczyk, E., Slaughter, R., 2010. New generations of futures methods. Futures 42, 75-82. http://dx.doi.org/10.1016/j.futures.2009.08.011.

Laffont, L., 2012. Cooperative learning and tutoring in sports and physical activities. In: Dyson, B., Casey, A. (Eds.), Cooperative Learning in Physical Education: A Research-based Approach. Taylor \& Francis Group, Routledge, pp. 136-149.

Mermet, L., 2009. Extending the perimeter of reflexive debate on futures research: an open framework. Futures 41, 105-115. http://dx.doi.org/10.1016/j.futures.2008.07.044.

Miller, R., 2007. Futures literacy: a hybrid strategic scenario method. Futures 39, 341-362. http://dx.doi.org/10.1016/j.futures.2006.12.001.

Miller, R., 2015. Learning, the future, and complexity. An essay on the emergence of futures literacy. Eur. J. Educ. 50, 513-523. http://dx.doi.org/10.1111/ejed.12157.

Nelson, R., 2010. Extending foresight: the case for and nature of Foresight 2.0. Futures 42, 282-294. http://dx.doi.org/10.1016/j.futures.2009.11.014.

Neugarten, M.L., 2006. Foresight-Are we looking in the right direction? Futures 38, 894-907. http://dx.doi.org/10.1016/j.futures.2005.12.013.

van Notten, P.W., Rotmans, J., van Asselt, M.B., Rothman, D.S., 2003. An updated scenario typology. Futures 35, 423-443. http://dx.doi.org/10.1016/S0016-3287(02)00090-3.

Özkaynak, B., Rodríguez-Labajos, B., 2010. Multi-scale interaction in local scenariobuilding: a methodological framework. Futures 42, 995-1006.

http://dx.doi.org/10.1016/j.futures.2010.08.022. 
Patel, M., Kok, K., Rothman, D.S., 2007. Participatory scenario construction in land use analysis: an insight into the experiences created by stakeholder involvement in the Northern Mediterranean. Land Use Policy 24, 546-561. http://dx.doi.org/10.1016/j.landusepol.2006.02.005.

Plieninger, T., Bieling, C., Ohnesorge, B., Schaich, H., Schleyer, C., Wolff, F., 2013. Exploring futures of ecosystem services in cultural landscapes through participatory scenario development in the Swabian Alb, Germany. Ecol. Soc. 18, 39. http://dx.doi.org/10.5751/ES-05802-180339.

Poli, R., 2015. The implicit future orientation of the capability approach. Futures 71, 105-113. http://dx.doi.org/10.1016/j.futures.2015.03.002.

Popper, R., 2009. Mapping Foresight: Revealing How Europe and Other World Regions Navigate Into the Future. EFMN. Publications Office of the European Union, European Commission, Luxembourg.

Pourezzat, A.A., Mollaee, A., Firouzabadi, M., 2008. Building the future: undertaking proactive strategy for national outlook. Futures 40, 887-892. http://dx.doi.org/10.1016/j.futures.2008.07.024.

Ramirez, R., Wilkinson, A., 2014. Rethinking the $2 \times 2$ scenario method: Grid or frames? Technol. Forecast. Soc. Chang. 86, 254-264.

http://dx.doi.org/10.1016/j.techfore.2013.10.020.

Ramos, J.M., 2006. Dimensions in the confluence of futures studies and action research. Futures 38, 642-655. http://dx.doi.org/10.1016/j.futures.2005.10.008.

Ramos, J.M., 2010. Movements toward holism in futures inquiry. Futures 42, 115-124. http://dx.doi.org/10.1016/j.futures.2009.09.004.

Reed, M.S., Kenter, J., Bonn, A., Broad, K., Burt, T.P., Fazey, I.R., Fraser, E.D.G., Hubacek, K., Nainggolan, D., Quinn, C.H., Stringer, L.C., Ravera, F., 2013. Participatory scenario development for environmental management: a methodological framework illustrated with experience from the UK uplands. J. Environ. Manag. 128, 345-362. http://dx.doi.org/10.1016/j.jenvman.2013.05.016.

Ringland, G., 2010. The role of scenarios in strategic foresight. Technol. Forecast. Soc. Chang. 77, 1493-1498. http://dx.doi.org/10.1016/j.techfore.2010.06.010.

Sisto, R., van Vliet, M., Prosperi, M., 2016. Puzzling stakeholder views for long-term planning in the bio-economy: a back-casting application. Futures 76, 42-54. http://dx.doi.org/10.1016/j.futures.2015.04.002.

Slaughter, R.a., 2002. Futures studies as a civilizational catalyst. Futures 34, 349-363. http://dx.doi.org/10.1016/S0016-3287(01)00049-0. 
Slaughter, R., 2008. What difference does “integral” make? Futures 40, 120-137. http://dx.doi.org/10.1016/j.futures.2007.11.015.

Stevenson, T., 2006. From vision into action. Futures 38 (6), 667-672. http://dx.doi.org/10.1016/j.futures.2005.10.009.

Swart, R.J., Raskin, P., Robinson, J., 2004. The problem of the future: sustainability science and scenario analysis. Glob. Environ. Chang. 14, 137-146.

http://dx.doi.org/10.1016/j.gloenvcha.2003.10.002.

Tomlinson, I., 2013. Doubling food production to feed the 9 billion: a critical perspective on a key discourse of food security in the UK. J. Rural. Stud. 29, 81-90. http://dx.doi.org/10.1016/j.jrurstud.2011.09.001.

Varum, C.A., Melo, C., 2010. Directions in scenario planning literature - a review of the past decades. Futures 42, 355-369. http://dx.doi.org/10.1016/j.futures.2009.11.021.

Vecchiato, R., Roveda, C., 2010. Foresight in corporate organisations. Tech. Anal. Strat. Manag. 22, 99-112. http://dx.doi.org/10.1080/09537320903438179.

Vervoort, J.M., Bendor, R., Kelliher, A., Strik, O., Helfgott, A.E.R., 2015. Scenarios and the art of worldmaking. Futures. http://dx.doi.org/10.1016/j.futures.2015.08.009.

Wilkinson, A., Kupers, R., Mangalagiu, D., 2013. How plausibility-based scenario practices are grappling with complexity to appreciate and address 21st century challenges. Technol. Forecast. Soc. Chang. 80, 699-710.

http://dx.doi.org/10.1016/j.techfore.2012.10.031.

Wilkinson, A., Mayer, M., Ringler, V., 2014. Collaborative futures: integrating foresight with design in large scale innovation processes-seeing and seeding the futures of Europe. J. Futur. Stud. 18, 1-26.

Wodak, J., Neale, T., 2015. A critical review of the application of environmental scenario exercises. Futures. http://dx.doi.org/10.1016/j.futures.2015.09.002.

Wollenberg, E., Edmunds, D., Buck, L., 2000. Using scenarios to make decisions about the future: anticipatory learning for the adaptive co-management of community forests. Landsc. Urban Plan. 47, 65-77. http://dx.doi.org/10.1016/S0169-2046(99)00071-7.

Wright, G., Goodwin, P., 2009. Decision making and planning under low levels of predictabiity: enhancing the scenario method. Int. J. Forecast. 25, 813-825.

Wright, G., Bradfield, R., Cairns, G., 2013. Does the intuitive logics method - and its recent enhancements - produce "effective" scenarios? Technol. Forecast. Soc. Chang. 80 (4), 631-642. http://dx.doi.org/10.1016/j.techfore.2012.09.003. 
Robin Bourgeois is an agricultural economist and foresight practitioner from the French Agricultural Research Centre for International Development (CIRAD). He is currently a senior scientist at the Centre for the Sudy of Governance Innovation, University of Pretoria, South Africa. His current research focuses on anticipatory governance, rural development and empowerment. Before that, he worked at the Global Forum on Agricultural Research (GFAR) strengthening the role of foresight and providing open and multi-stakeholder spaces for dialogue and action on the future challenges for agricultural research for better development impact. Robin has a long practice of international organisations and experience of field research in numerous countries. His research domains include foresight, institutional change, inequality and poverty in rural development, collective decision-making in the elaboration of public policies.

Esther Penunia is the secretary-general of the Asian Farmers' Association for Sustainable Rural Development (AFA), a regional alliance established in 2002. Prior to this, she served as a nongovernmental organization executive and a community organizer. As a social development worker, Esther spent more than three decades working in the field of rural development alongside farmers, fishers and indigenous peoples as a community organizer, participatory action researcher, trainer, gender advocate, consultant, campaigns coordinator, NGO executive/manager and networker. In 2014, she was the International Year of Family Farming Special Ambassador for Asia.

Sonali Bisht is Founder and Advisor to the Institute of Himalayan Environmental Research and Education (INHERE), which works for community-based sustainable development in the central Himalayan region of India. She has been working on community based rural development and natural resource management issues for over three decades in various capacities with national and international organizations. Presently she is member of the Steering Committees of the Global Forum on Agricultural Research (GFAR), the global Agricultural Biodiversity Community and the Central Himalayan Environment Association. Sonali is a writer, consultant, development worker and advocate of issues of smallholder farmers.

Don Boruk is a farmer and the Head of the Boru Kedang village in the district of Wulanggitang, Flores Island, Nusa Tenggara Tenga Province. He is the Head of the Jaringan Petani Wulanggitang (JANTAN), a network of farmers in Wulanggitang with more than $\mathbf{1 1 0 0}$ members. Jantan is a member of Aliansi Petani Indonesia (Indonesian Peasant Alliance), a national federation of peasant organisations, where Don has also responsibilities. 


\section{Appendix 1. Roles and profiles of the supervisors and facilitators.}

The four supervisors from CIRAD, AFA, INHERE and API are the co-authors of this article (see their biographical notes). The first author, then Foresight Advisor at GFAR initiated the grassroots foresight initiative action research. The supervisor from AFA took the lead in organizing the field work in three countries, engaging member organizations through contractual agreements. Asian supervisors attended the full training workshop along with the facilitators. They gained a deep understanding of the approach and its implementation and developed a common culture with the facilitators. Their role was to ensure proper implementation, quality control and reporting of the results. They interacted with the facilitators along the different phases of the field work and provided logistical assistance.

The role of the facilitators was to implement the grassroots foresight initiative at local community level. For this purpose, they first all learned and acquired skills necessary to lead the initiative during a capacity-building workshop they all attended simultaneously. They translated the training material in the local languages in order to ensure full contribution of the participants. They selected the participants to the initiative using common selection principles provided to them during the training. They conducted the different sequences of the co-elaborative scenario building process. They recorded the results including intermediary outputs using standard formats and reported to the supervisors accordingly.

The functions of the facilitator included making sure that all participants were given an equal opportunity to intervene, and that the basic steps and rules agreed upon were understood and followed. They were in charge of ensuring that agreements were reached before moving from one step to the next one. Their profiles and specific roles were as follows.

\section{India}

Mr. M. M. has a post graduate degree (MSc Geology) with keen interest in community based development work in mountain areas of the central Himalayan region of India. He has been working for over 22 years in community based development projects with a focus on natural resource development and management. He is experienced in adapting new concepts and bringing them live as local communities identify with them and work on them.

Mr. S. K. S. has a post graduate degree in agriculture. He has been actively engaged in agriculture issues at local and national levels in India. He has a good understanding of farming communities of the central Himalayan region and has experience of training farmers to increase production and productivity as well meeting the various challenges they face with agriculture as their main source of livelihood. He has been assisting rural development projects in the area of agriculture improvement 
and natural resource management with focus on sustainability. He maintains good links with academics, research and smallholder farmers engaged in agriculture.

Mr. M. M. and Mr. S. K. S. were instrumental in coordinating translation work, selection of participants and organizing of foresight workshop as well as for facilitation and inclusion of participants with different levels of education and areas of experience.

A support team of seven additional staff members of INHERE played a critical supportive role in explaining, translating, dealing with local dialects, explaining concepts, bolstering, supporting, ensuring engagement of some of the women participants as well as dealing with and neutralizing hierarchies of age, qualification, positions, gender, language and geographies (rural-urban). The founder of INHERE and Mentor was instrumental in bringing to fore difficulties and sensitivities in conducting the foresight workshop and working out strategy to deal with them for timely completion and effective results.

\section{Indonesia}

Mr. D. B. D. is the Chairperson of API's NTT chapter, head of the Boru village and a respected and leader of Boru Kedang Indigenous People Community. He played a crucial role in planning, organizing and implementing the grassroots foresight initiative. He adapted the methodology to the local conditions, having to work with three different languages.

Mr. G. S. B. is an administrator of API's NTT Chapter in Indonesia. He is a member of the Boru Kedang Indigenous People Community and was chosen as a facilitator for his understanding of English. He played a crucial role in translating the method and material in the workshop's languages and reporting the results in English. He also played an important role in explaining the methodology to the participants and facilitating its implementation.

\section{Philippines}

Mr. J. S. is an artisanal fisher in Bugsuk Island, Balabac town, located at southern Palawan province in the Philippines. He belongs to the indigenous Pal'wan community. He is one of the elected council leaders in his village. He is likewise a leader of a community-based organization called "SAMBILOG" (meaning "One") , composed mainly of Pal'wan indigenous group, which is struggling to claim ancestral lands and waters through the government's agrarian and indigenous people's rights program. SAMBILOG is a member organization of PAKISAMA, which is a national confederation of small scale women and men farmers, fishers and indigenous peoples. In this local grassroots foresight initiative, he provided the political leadership in mobilizing SAMBILOG leaders to take active participation. 
Ms. D. R. is a graduate of Social Work at Miriam College in the Philippines. Her first job after graduation was to join PAKISAMA as one of its community organizers. She was assigned to help PAKISAMA in assisting SAMBILOG in claiming ancestral lands and waters. She implemented the foresight exercises at the local level, mobilizing the SAMBILOG leaders, translating the foresight training materials and exercises in the national language, and facilitated the foresight exercise. 